\title{
A Case of Cutaneous Leishmaniasis Responding to Systemic Liposomal Amphotericin B Treatment
}

\section{Sistemik Lipozomal Amfoterisin B Tedavisine Cevap Veren Kutanöz Leishmaniasis Olgusu}

\author{
Esra Çakmak Taşkın'(iD), Hatice Büşra Kütükçü'(iD), Hatice Kübra Konca'(iD), Gül Arga'(iD), Halil Özdemir'(iD), \\ Bengü Nisa Akay ${ }^{3}(\mathrm{I} D)$, Ergin Çiftçi'(iD), Erdal İnce'(iD) \\ ${ }^{1}$ Division of Pediatric Infectious Diseases, Department of Pediatrics, Ankara University School of Medicine, Ankara, Turkey \\ 2 Department of Pediatrics, Ankara University School of Medicine, Ankara, Turkey \\ ${ }^{3}$ Department of Skin and Venereal Diseases, Ankara University School of Medicine, Ankara, Turkey
}

Cite this article as: Çakmak Taşkın E, Kütükçü HB, Konca HK, Arga G, Özdemir H, Akay BN, et al. A case of cutaneous leishmaniasis responding to systemic liposomal amphotericin b treatment. J Pediatr Inf 2020;14(4):e229-e232.

Abstract

Leishmania is a vector-induced endemic tropical disease caused by protozoans. The most common cutaneous, mucosal and visceral forms are the cutaneous form. The main drugs in treatment are pentavalent antimony compounds, but their side effects create limitation of use. Local antimony compounds are used primarily in the treatment of cutaneous leishmaniasis. In some cases, alternative treatment modalities are required due to insufficient response to local treatment. Systemic amphotericin B treatment is one of the alternative treatments. In a patient who developed cutaneous Leishmania at 21 months and who did not respond with local meglumine antimoniate therapy, a total of $21 \mathrm{mg} / \mathrm{kg}$ dose of systemic amphotericin B was given intermittently and successful results were obtained.

Keywords: Amphotericin B, cutaneous leishmania, meglumine antimoniate

\section{Introduction}

Leishmaniasis is an endemic tropical disease originating from vectors and is caused by several protozoan parasite
Öz

Leishmania, protozoonların neden olduğu, vektör kaynaklı endemik bir tropikal hastalıktır. Kutanöz, mukozal ve visseral formları içinde en sık görüleni kutanöz formdur. Tedavide esas ilaç pentavalan antimon bileşiklerdir, ancak yan etkileri kullanım kısıtılığı yaratmaktadır. Kutanöz Leishmania tedavisinde öncelikle lokal antimon bileşikleri kullanılır. Bazı vakalarda lokal tedaviye yanıtın yetersiz olması nedeniyle alternatif tedavi uygulamaları gerekir. Sistemik amfoterisin B tedavisi alternatif tedavilerden biridir. Bizde 21 aylık yüzde kutanöz Leishmania gelişen ve lokal meglumin antimonat tedavisi ile yanıt alınamayan bir hastada toplam $21 \mathrm{mg} / \mathrm{kg}$ dozda sistemik amfoterisin B aralıklı verilerek başarılı sonuç elde edilmiştir.

Anahtar Kelimeler: Amfoterisin B, kutanöz leishmania, meglumin antimonat

Leishmania (1). Current data show that the number of new cases annually is approximately 1 million, the number of total cases is 12 million, and more than 350 million people are at risk of infection worldwide (2).

\section{Correspondence Address / Yazışma Adresi}

Esra Çakmak Taşkın

Ankara Üniversitesi Tıp Fakültesi,

Çocuk Sağlığı ve Hastalıkları Anabilim Dalı,

Çocuk Enfeksiyon Hastalıkları Bilim Dalı,

Ankara-Türkiye

E-mail: esracakmaktaskin@gmail.com 
Leishmaniasis is seen typically in three different forms including localized cutaneous, mucosal and visceral disease (1). Mucosal leishmaniasis is a disease involving and destroying the cartilages, pharynx, larynx, and the skeletal structure of the face $(3,4)$. Visceral leishmaniasis is a dangerous disease where fever and splenomegaly are at the forefront and mortality can occur if left untreated. Cutaneous leishmaniasis (CL) can mimic many diseases clinically. Infections, malignancy and diseases like pyoderma gangrenosum should be considered in differential diagnosis (3). Visceral leishmaniasis must be considered in the presence of fever and splenomegaly in cases especially with a history of travel to endemic regions.

The main drug used in the treatment of leishmaniasis is the compounds of pentavalent antimony; however, various problems occur in their use due to side effects. Recently, liposomal Amphotericin $B$ has become a prominent drug in treatment. This study aimed at reporting a cutaneous leishmaniasis case who responded insufficiently to meglumine antimony treatment but treated successfully with systemic liposomal amphotericin B.

\section{Case Report}

A 21-month-old male patient presented with a lesion on his face ongoing for one and a half years. It was found out that the lesion on his face developed when the patient was four months old and that there was a history of travel to Şanlıurfa in that period. Upon the enlargement of the lesion that had started as an acne and becoming black and crusted in the center, the patient applied to dermatology, and considering oriental sore, skin scraping was performed and plenty of amastigotes were seen in the smear. The patient was then started on intralesional 6 doses of meglumine antimonate (about 1 $\mathrm{mL} / \mathrm{cm}^{2}$ ) to whiten all the lesion, but following a small degree shrinkage and then a re-enlargement of the lesion, the patient was referred to our pediatric infectious diseases clinic by dermatology. The patient was admitted to the ward for systemic treatment due to the fact that the lesion was on the face, $4 \mathrm{~cm}$ in size and did not respond to local treatment. Physical examination revealed a sharply-circumscribed lesion on the right cheek, $4 \times 3 \mathrm{~cm}$ in size, with an ulcerated center and indurated and paler surrounding. Mucosal involvement and hepatosplenomegaly were not detected. Amastigote was not seen in the smear performed from skin scraping. Leishmania IgG (IFA) $1 / 64$ was detected positive, PCR negative. The patient was started on $3 \mathrm{mg} / \mathrm{kg}$ intravenous (iv) liposomal Amphotericin $B$ treatment with the diagnosis of cutaneous leishmaniasis. Amphotericin $B$ was repeated on the $14^{\text {th }}$ and $21^{\text {st }}$ days for the patient who received the treatment every day for the first 5 days. An apparent shrinking was seen as of the $4^{\text {th }}$ dose of the treatment. It was seen in the patient who received a total of 7 doses that the lesion shrank to $0.5 \mathrm{~cm}$ forming fibrotic bands towards the center two weeks after the last dose. The lesion was cured leaving a very small scar following a 6-month follow-up.

\section{Discussion}

The agents of Leishmania endemic in the Southeastern Anatolia region and in Çukurova in our country are L. tropica an L. infantum. While L. tropica causes anthroponotic (transmission from humans to humans through a vector) cutaneous leishmaniasis, L. infantum and L. major causes zoonotic cutaneous leishmaniasis. The main reservoir of $L$. infantum is the Canidae family (dog, wolf, coyote, fox) and that of L. major is rodents. In our country, L. tropica is most commonly seen in the province of Şanlıurfa $(5,6)$. In our case, history of travel to Şanlıurfa was present.

The first skin finding in $\mathrm{CL}$ develops several weeks after contact (7). Infection frequently occurs between April and September, and it is most commonly reported between June and August (6-8). The lesion in cutaneous form starts as an erythematous papule in places that cannot be covered by clothes including the face, neck and extremities where the fly
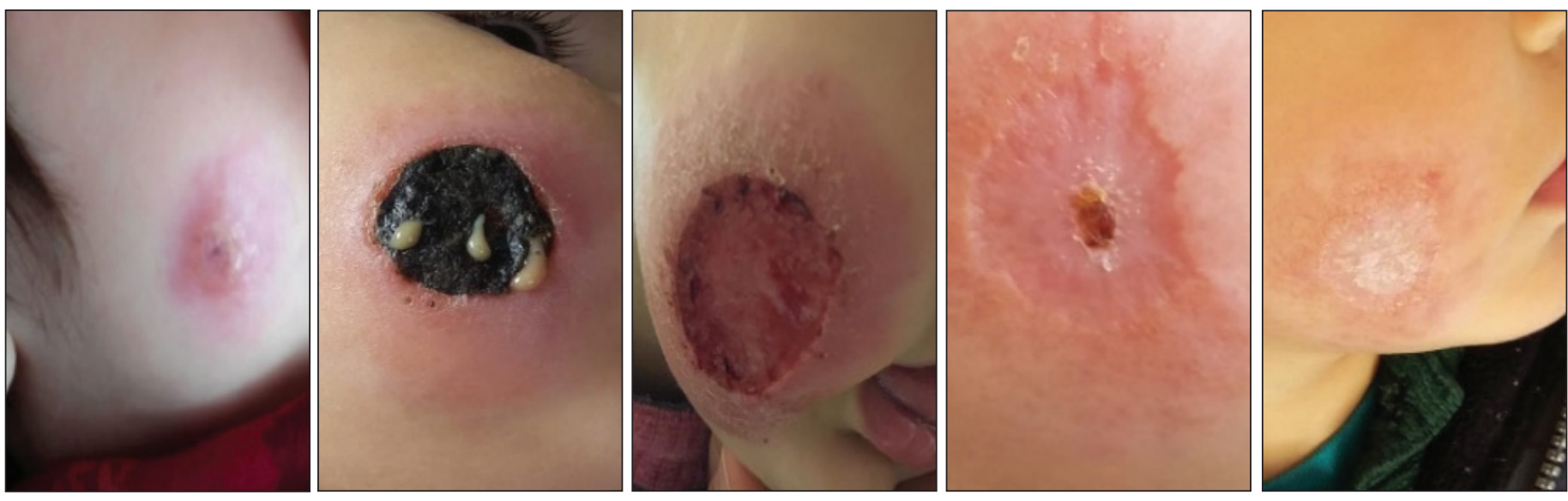

Figure 1,2,3,4 and 5. Images of lesion in the first days, at admission to our hospital and after systemic treatment. 
bites. Growing slowly, it transforms into a nodule or a plaque with an ulcerated center covered with a crust that is tightly attached to the surrounding weeks-months later. If the hard crust is removed, nail-like protrusions under the crust can be seen (Hulusi Behçet's nail sign). It is painless and heals leaving a scar. Lifelong immunity is established when healed. Patients apply to healthcare institutions with only aesthetic concerns due to the fact that the lesions are painless, heal spontaneously and do not cause systemic complications (5-8).

$\mathrm{CL}$ diagnosis is made with suspected epidemiological and clinical history and is supported by laboratory tests. Living in an endemic region or travelling to such regions is important (6). Definitive diagnosis is based on seeing amastigote forms of the parasite with microscopic investigation of the smears taken by skin scraping. Dermal macrophages appear with a blue-gray color in cytoplasm with hematoxylin eosin dye (3). Moreover, diagnosis can be made by producing promastigote forms of the parasite in the Novy-Nicolle-McNeal medium. Rarely, diagnosis can be made with serologic diagnostic methods like enzyme immune assay or indirect immunofluorescent antibody test or with methods like polymerase chain reaction $(5,6)$.

When the lesions of the patients with $\mathrm{CL}$ are evaluated under a dermoscope, erythematous and vascular structures along with yellow, tear-like structures corresponding to keratin plugs and a pattern similar to parakeratotic hyperkeratosis in the shape of a starburst have been observed (3). In our case, dermoscopy revealed yellow, tear-like structures.

Leishmania is a disease difficult to treat. While systemic treatment is always given to visceral and mucocutaneous leishmaniasis, not all has to be treated in the cutaneous form. Treatment in cutaneous leishmaniasis varies according to the place and size of the lesion and immune status of the patient. To that end, local or systemic treatments can be used $(9,10)$.

The purpose in treatment is clinical recovery not parasitological treatment. Other goals of the treatment include reducing local damage and functional losses to the minimum, speeding up recovery and decreasing the possibility of recurrence (11).

Topical paromomycin, intralesional pentavalent antimonies and physical methods (cryotherapy, local heat, surgery, curettage, electrodesiccation and $\mathrm{CO}_{2}$ laser) are used in local treatment (3). Primary treatment approach in non-complicated $C L$ cases is local treatment. However, sufficient recovery may not be obtained. There are two pentavalent antimony compounds containing therapeutically-equivalent meglumine antimonate and sodium stibogluconate. The drug is directly administered inside the lesion without any dilution in intralesional implementation (12). Cure rate in adults with old world cutaneous leishmaniasis has been reported as high as
95\% when treated with intradermal sodium stibogluconate three times a week for two months, and recurrence has been seen in $4 \%$ of the cases (3). Topical liposomal Amphotericin B formulations have also been used in the treatment of $C L$. $\ln L$. infantum, a preparation containing $2 \%$ Amfotericin B has been administered twice a day for 12 weeks, and the treatment has been a success (13). Full recovery has been observed in a patient with cutaneous leishmaniasis on his/her face, receiving $0.1 \%$ Amphotericin B gel twice daily for 6 months (14). In our patient, intralesional meglumine antimonate was applied first, but a partial response was received.

Systemic treatment is recommended in lesions located on cosmetically important places like the face and ears, in cases that do not ameliorate 2-3 months after local treatment, in lesions on the joints and feet-hands, in the presence of spread, in immunosuppressed patients, in more than 4 lesions, in the presence of mucosal involvement and in cases in whom nodular lymphangitis has occurred $(11,14)$.

Pentavalent antimonies, pentamidine, and amphotericin B are used as parenteral agents in the treatment of cutaneous leishmaniasis. Antimonies usually make up the basis of systemic treatment for $\mathrm{CL}$. The recommended dose is $20 \mathrm{mg} / \mathrm{kg} /$ day for 20 days in cutaneous leishmaniasis and for 28-30 days in visceral leishmaniasis. There is treatment chance without significantly increasing toxicity with these doses. Side effects like anomalies in cardiac conduction and high serum transaminase and pancreatic enzyme levels have been reported in antimonial treatment. Investigation of other treatments has become more common due to route of administration, side effect profile and development of resistance to antimonial drugs (3).

Amphotericin B is used in the treatment of leishmaniasis in some parts of the world, especially in places where antimonial resistance is high. The drug increases the permeability of the cell membrane of the parasite and leads to the death of promastigotes and amastigotes encouraging ion flow. The literature contains information on the doses of Amphotericin B. Amphotericin $B$ deoxycholate is also effective in the treatment of Leishmania, but its use is limited and there are constraints in its use due to renal toxicity. Liposomal Amphotericin B can allow for a lower toxicity and shorter length of treatment (11).

In the treatment of larger lesions resistant to local therapy, liposomal amphotericin B is an effective and well-tolerated option and can be used considering the high cost of the treatment and need for hospitalization in countries where pentavalent antimonial treatment is not possible and in infections caused by types that respond poorly to this treatment. Various treatment regimens with a total cumulative dose of $20-25 \mathrm{mg} / \mathrm{kg}$ body weight have been found effective against $\mathrm{CL}$ and mucocutaneous leishmaniasis. Despite high toxicity 
of Amphotericin B, better clinical response and lower relapse rates have been reported in comparison to systemic pentavalent antimony compounds (15).

A very low side effect rate has been established when total dosage is used as $15-20 \mathrm{mg} / \mathrm{kg}$ in studies conducted with liposomal amphotericin B (3). In our patient, we observed total recovery with a small scar and no significant side effect with a total $21 \mathrm{mg} / \mathrm{kg}$ iv liposomal amphotericin B treatment.

Leishmania is an infection whose prevalence can decrease if appropriate measures are taken. Since limewater can easily spoil the habitat of sand flies, the trees on which sand flies rest are recommended to be limewashed up to 1-1.5 m height from the ground instead of having the trees disinfected or cut. In order to prevent contact with the vector, insecticide-treated nets can be used. Fly screen on doors and windows and the use of ventilators and air conditioner in indoors can be helpful. It is recommended to wear long-sleeved clothes and use fly-repellent compounds during the hours sand flies are active (6).

In conclusion, $\mathrm{CL}$ should be brought to mind skin lesions that develop in cases living especially in endemic regions or having a history of travel to such regions. Systemic treatment must be initiated in patients with large lesions and critical localizations similar to our case. Amphotericin B can be a better option compared to antimony compounds in systemic treatment, and when used at the appropriate dose and length like in our patient, dramatic outcomes can be obtained in treatment. There is no consensus regarding the dose of Amphotericin B. Studies on this subject continue, and it can replace antimony compounds in cases with cutaneous leishmaniasis in the future.

Informed Consent: Patient consent was obtained.

Peer-review: Externally peer-reviewed.

Author Contributions: Concept - El, EÇT; Design - EÇT, El; Supervision - El; Resources - BNA, El; Data Collection and/or Processing - EÇT, HBK; Analysis and/or Interpretation - El, HÖ, EÇ; Literature Review - EÇT, GA, HKK; Writing - EÇT; Critical Review - EÇ, HÖ.

Conflict of Interest: No conflict of interest was declared by the authors.

Financial Disclosure: The authors declared that this study has received no financial support.

\section{References}

1. Uzun S. Leishmaniasis. (eds). Tüzün Y, Gürer MA, Serdaroğlu S, Oğuz O, Aksungur VL. Dermatololoji. İstanbul:Nobel Tip Kitabevleri. 2008:65982. [CrossRef]

2. World Health Organization (WHO). Leishmaniasis. World Health Organization. (Available from: https://www.who.int/health-topics/ leishmaniasis). [CrossRef]

3. Handler MZ, Patel PA, Kapila R, Al-Qubati Y, Schwartz RA. Cutaneous and mucocutaneous leishmaniasis: Differential diagnosis, diagnosis, histopathology and management. J Am Acad Dermatol 2018;73:91126. [CrossRef]

4. Tuon FF, Santos CR, Cieslinski J, Souza RM, Imamura R, Amato VS. Treatment of mucosal leishmaniasis with amphotericin B lipid complex (ABLC). Rev Inst Med Trop São Paulo 2018;60:e71. [CrossRef]

5. Ölmez D, Babayiğit A, Kuşku E, Uzuner N, Alaygut D, Akarsu S, ve ark. Bir pediatrik kutanöz leishmaniasis olgusu. Dokuz Eylül Üniversitesi Tıp Fakültesi Dergisi 2007;21:97-101. [CrossRef]

6. Ser Ö, Cetin H. Kutanöz leishmaniasis ve Antalya ilindeki durumu. Türkiye Parazitoloji Dergisi 2013;37:84-91. [CrossRef]

7. Çulha $G$, Akçali C. Hatay ve çevresinde saptanan kutanöz leishmaniasis olguları. Türkiye Parazitoloji Dergisi 2006;30:267-71. [CrossRef]

8. Bayazıt $Y$, Özcebe H. Şanlıurfa ili kent merkezinde kutanöz leishmaniasis insidans ve prevalansı. Türk Hijyen ve Deneysel Biyoloji Dergisi 2004;61(1):9-14. [CrossRef]

9. Kirchberger MC, Schliep S, Bogdan C. Rhinophyma-like cutaneous leishmaniasis due to leishmania aethiopica treated successfully with liposomal amphotericin B. Am J Trop Med Hyg 2019;100:231-2. [CrossRef]

10. American Academy of Pediatrics. Leishmaniasis. In: Kimberlin DW, Brady MT, Jackson MA, Long SS (eds). Red Book: 2018-2021 Report Of the Committee On Infectious Diseases. 31 ${ }^{\text {st }}$ ed. Itasca, IL. 2018:501-4. [CrossRef]

11. Nguyen AK, Yang K, Bryant K, Li J, Joice AC, Werbovetz KZ, et al. Microneedle-based delivery of amphotericin $b$ for treatment of cutaneous leishmaniasis. Biomedical Microdevices 2019;21:1-10. [CrossRef]

12. Uzun S, Gürel MS, Harman M. Kutanöz. Layşmanyazis tanı ve tedavi rehberi. Türk Dermatoloji Derneği. 2017. [CrossRef]

13. Alcntara-Reifs CM, Garnacho-Saucedo G, Salido-Vallejo R, García-Nieto AV. Topical amphotericin B for the treatment of localized cutaneous leishmaniasis. Dermatol Ther 2017;30:e12402. [CrossRef]

14. Gupta A, Sardana K, Ahuja A, Kishan Gautam R. Complete cure of a large complex cutaneous leishmaniasis with a nonethanolic lipid based-amphotericin B gel. Clin Exper Dermatol 2018;44:807-10. [CrossRef]

15. Wijnant GJ, Bocxlaer KV, Francisco AF, Yardley $V$, Harris A, Alavijeh $M$, et al. Local skin Inflammation in cutaneous leishmaniasis as a source of variable pharmacokinetics and therapeutic efficacy of liposomal amphotericin B. Antimicrobial Agents Chemotherapy 2018;62:e0063118. [CrossRef] 